\title{
Nyamwezi Language
}

National Cancer Institute

\section{Source}

National Cancer Institute. Nyamwezi Language. NCI Thesaurus. Code C154063.

A Niger-Congo Bantu language spoken in central Tanzania. 